Maxiselly, Y. · A. Ismail · S. Rosniawaty · I.R.D. Anjarsari

\title{
Skrining fitokimia cangkang dan kulit batang tanaman jengkol asal Ciamis Jawa Barat sebagai inisiasi obat diabetes mellitus berbahan alam
}

\section{Phytochemical screening of jengkol shells and tree bark origin from ciamis west java as initiated of diabetic mellitus natural medicine}

Diterima : 15 September 2015/Disetujui : 15 Oktober 2015 / Dipublikasikan : Oktober 2015

CDepartment of Crop Science, Padjadjaran University

\begin{abstract}
Development of natural medicine is increasing due to consider the pattern of society now prefer life back to nature. Jengkol is one of the plants that have potential as natural medicine. The useful contents of jengkol are the amino acid, vitamin, mineral, also other substances such as saponins, flavonoids, and tannins indispensable for human. Another jengkolpotential is capable of lowering blood sugar levels so as to prevent the Diabetes Mellitus (DM) disease. Parts of jengkol had studied antidiabetic agent are the tree bark, fruit shells and seeds. This study examined the phytochemical content in the jengkol shell and tree bark from Ciamis West Java district which has been collected by the Laboratory of Crop Production Faculty of Agriculture, University of Padjadjaran as a preliminary stage for the development of jengkol as a natural medicine. The study was conducted in November 2013 - January 2014 in the laboratory Faculty of Pharmacy, Padjadjaran University with using 12 samples consisting of parts of jengkol shells and bark. Test results showed there is a variation of phytochemical contents that existed at the shell and bark of jengkol. Ten of the twelve samples contain phenolics and terpenoids, so the potential to be developed as a natural material, one of which serves to lower blood sugar levels. Other components contained in the samples tested are alkaloids, saponins, quinones, and flavonoids which are also secondary metabolites in plants.
\end{abstract}

Keywords: Jengkol • Phytochemical contents . West Java

\footnotetext{
Dikomunikasikan oleh Agus Wahyudin

Maxiselly, Y. ${ }^{1 .}$. A. Ismail ${ }^{1}$. S. Rosniawaty ${ }^{1}$. I.R.D. Anjarsari ${ }^{1}$

1 Dept. Budadaya Pertanian Fakultas Pertanian Unpad

Korespondensi: yudithia.maxiselly@gmail.com
}

Sari Pengembangan obat bahan alam semakin meningkat karena mempertimbangkan pola masyarakat yang kini lebih memilih hidup back to nature.Jengkol merupakan salah satu tanaman yang memiliki potensi sebagai obat bahan alam. Kandungan jengkol yang bermanfaat yaitu asam amino, vitamin, mineral, juga zat lain seperti saponin, flavonoid, dan tannin sangat dibutuhkan manusia. Potensi jengkol lainnya adalah mampu menurunkan kadar gula dalam darah sehingga dapat mencegah penyakit Diabetes Mellitus (DM). Bagian jengkol yang diteliti memiliki zat antidiabetes adalah kulit batang, cangkang buah dan bijinya. Penelitian ini bertujuan melihat kandungan fitokimia pada cangkang dan kuit batang jengkol asal Ciamis Jawa Baratyang telah berhasil dikoleksi oleh Laboratorium Produksi Tanaman Fakultas Pertanian Universitas Padjadjaran sebagai tahap awal untuk dikembangkannya jengkol sebagai salah satu obat bahan alam. Penelitian dilakukan pada November 2013 Januari 2014 di Laboratorium Farmasi Unpad dengan menggunakan 12 sampel yang terdiri dari bagian cangkang dan kulit batang jengkol. Hasil pengujian menunjukan terdapat variasi dari kandungan fitokimia yang ada pada cangkang dan kulit batang jengkol. Sepuluh dari dua belas sampel memiliki kandungan fenolat dan terpenoid sehingga berpotensi untuk dikembangkan sebagai bahan alam yang salah satunya berfungsi untuk menurunkan kadar gula darah. Kandungan lainnya yang terkandung pada sampel yang diuji adalah alkaloid, saponin, kuinon, dan flavonoid yang juga merupakan metabolit sekunder pada tanaman.

Kata kunci : Jengkol - Kandungan fitokimia • Jawa Barat 


\section{Pendahuluan}

Jengkol merupakan tanaman yang sudah tidak asing di masyarakat Indonesia. Tanaman ini sering digunakan sebagai bahan pangan olahan yang cukup digemari. Selain sebagai bahan pangan, jengkol juga digunakan sebagai pestisida alami dan obat berbagai penyakit. Teknologi terkini menghasilkan pengetahuan tentang kemampuan jengkol sebagai pestisida alami karena kandungan asam jengkolat dengan konsentrasi tinggi yang terdapat di jengkol mampu merusak ginjal dari hama golongan mamalia (Malik, 2010).

Berdasarkan penelitian sebelumnya ternyata pada cangkang buah, biji dan kulit batang jengkol memiliki kandungan zat anti diabetes yang beraktifitas secara hipoglikemia. Biji jengkol juga dilaporkan dapat meningkatkan insulin pada pankreas sehingga mengurangi resiko terkena diabetes mellitus (Evacuasiany dkk, 2004). Berdasarkan penelitian Razak et al (2010) menunjukan bahwa biji dan cangkang buah sama-sama memiliki efek hipoglikemia dan menurunkan kadar glukosa yang kemungkinan di sebabkan oleh aktifitas enzim. Kandungan tersebut terdapat pada biji, kulit batang, dan daun jengkol yang juga berupa saponin, flavonoid, dan tanin (Elysa, 2011).

Diabetes Mellitus (DM) merupakan salah satu penyakit berbahaya yang hingga kini sulit diobati.Menurut data WHO (World Health Organization), Indonesia menempati urutan keempat terbesar dalam jumlah penderita diabetes mellitus di dunia setelah Amerika Serikat, India, dan Cina. Jumlah penderita diabetes mellitus di Indonesia diperkirakan mengalami peningkatan dari 8,4 juta jiwa pada tahun 2000 menjadi sekitar 21,3 juta jiwa pada tahun 2030 mendatang (Elysa 2011).Pola hidup manusia sekarang yang kembali pada hal alamiah membuat obat herbal atau obat yang berasal dari bahan alam berupa ekstrak tanaman menjadi alternatif untuk mengatasi masalah penyakit yang belum mampu tertangani secara medis, salah satunya adalah diabetes mellitus yang dipercaya dapat dicegah dengan mengkonsumsi jengkol.

Provinsi pemasok jengkol di pasaran adalah Sumatra Utara, Jawa Barat dan Jawa Tengah serta beberapa daerah di Kalimantan. Salah satu daerah Jawa Barat yang masih mengembangkan jengkol adalah Ciamis (Kompas, 2013). Jengkol asal Ciamis selama ini hanya memasok kebu- tuhan pasar namun belum dilihat dari kandungan fitokimianya sehingga pengembangannya untuk industri farmaka belum banyak. Oleh karena itu sangat diperlukan kegiatan skrining fitokimia jengkol asal Ciamis Jawa Barat untuk mengetahui kandungan metabolit sekunder jengkol sebagai bentuk pengembangan awal obat bahan alam. Penelitian ini merupakan lanjutan dari kegiatan explorasi jengkol yang berhasil dikoleksi oleh Laboratorium Produksi Tanaman pada tahun 2013.

\section{Bahan dan Metode}

Bahan yang digunakan adalah 12 sampel cangkang dan kulit batang jengkol dari 7 aksesi (JG 16, JG 20, JG 21, JG 10, JG 11, JG 9, dan JG 12) yang merupakan koleksi Laboratorium Produksi tanaman Fakultas Pertanian Universitas Padjadjaran. Aksesi yang dikoleksi berasal dari Ciamis Jawa Barat dalam fase tanaman yang berbeda sehingga ada aksesi yang mampu di analisis cangkangnya karena memasuki fase generatif namun ada aksesi yang hanya mampu di analisis kulit batangnya saja karena masih berada di fase vegetatif.Sampel dibersihkan terlebih dahulu dan dikeringkan hingga kadar air $5 \%$ kemudian digiling hingga menjadi serbuk. Bahan kimia yang digunakan pereaksi Dragendorff, pereaksi Mayer, pereaksi Bouchardat, $\mathrm{NaOH} 10 \%$, Serbuk logam $\mathrm{Mg}, \mathrm{HCl}$ pekat, $\mathrm{FeCl} 31 \%$, H2SO4 pekat, Serbuk logam Zn,Asetat anhidrida, Kalium iodida, Iodium, Bismut (II)nitrat, HNO3, Raksa (II) klorida, Cerium sulfat $1 \%, \mathrm{NaOH} 2 \mathrm{~N}$, Etanol $95 \%$, Metanol, Eter, dan Etil asetat. Pengujian di lakukan di laboratorium Farmasi Universitas Padjadjaran pada bulan November 2013 - Januari 2014, meliputi analisis alkaloid, Polifenolat, Flavonoid, Saponin, Kuinon, Tanin, Monoterpen dan Steroid berdasarkan prosedur yang telah dilakukan oleh Harbone (1996).

\section{Hasil dan Pembahasan}

Sampel jengkol yang diuji dikoleksi dari daerah yang memiliki ketinggian tempat yang berbeda. Aksesi JG 12 berasal dari lokasi yang memiliki ketinggian tempat 425 mdpl, sedangkan JG 9, JG 10, JG11 dan JG 16 memiliki asal usul ketinggian tempat 500-600 mdpl dan JG 20 dan JG 21 berasal dari daerah yang ber-altitude $>700 \mathrm{mdpl}$ (Maxiselly dan Ustari, 2014). Ketinggian tempat 
Tabel 1. Hasil Skrining Fitokimia Cangkang Buah dan Kulit Batang Jengkol.

\begin{tabular}{|c|c|c|c|c|c|c|c|c|c|}
\hline No & Sampel & Alkaloid & Polifenolat & Flavonoid & Saponin & Kuinon & Tanin & Monoterpen & Steroid \\
\hline 1 & cangkang JG 16 & - & + & + & + & + & - & + & - \\
\hline 2 & Kulit Batang JG 16 & - & + & + & + & + & - & + & - \\
\hline 3 & cangkang JG 20 & - & + & + & + & - & + & + & - \\
\hline 4 & Kulit Batang JG 20 & + & + & + & + & - & - & + & - \\
\hline 5 & cangkang JG 21 & + & + & + & + & - & - & + & - \\
\hline 6 & Kulit batang JG 21 & + & - & + & + & - & - & + & - \\
\hline 7 & Kulit batang JG 10 & + & + & + & + & + & - & + & - \\
\hline 8 & Kulit batang JG 11 & + & + & + & + & + & - & + & - \\
\hline 9 & Cangkang JG 11 & + & - & + & + & + & - & + & - \\
\hline 10 & Kulit batang JG 9 & + & + & + & + & + & - & + & - \\
\hline 11 & Kulit batang JG 12 & + & + & + & + & + & - & + & - \\
\hline 12 & Cangkang JG 12 & + & + & + & + & + & - & + & - \\
\hline
\end{tabular}

Ket : + = terdapat kandungan, - = tidak terdapat kandungan

yang merupakan salah satu faktor iklim akan mempengaruhi produktifitas suatu tanaman termasuk kandungan dari metabolit sekunder. Salah satu metabolit sekunder yaitu alkaloid pada tanaman kina berupa kandungan kinine dipengaruhi oleh faktor dalam dan factor luar seperti ketinggian tempat (Astika dan Sriyadi, 1995).Hal ini juga dapat menjadi dasar yang mengakibatkan terdapat perbedaan kandungan fitokimia yang terdapat pada sampel yang diuji.

Hasil skrining menunjukan variasi dari kandungan fitokimia yang ada pada cangkang dan kulit batang jengkol. Seluruh sampel yang diuji memiiki kandungan flavonoid, saponin, dan Monoterpen, hanya terdapat 2 sampel yang menunjukan hasil negative pada pengujian polifenolat yaitu pada kulita batang JG 21 dan cangkang JG 11. Terdapat 9 sampel yang memiliki kandungan alkaloid sedangkan tiga sampel negatif yaitu kulit batang dan cangkang JG 16 serta cangkang JG 20.Alkaloid, flavonoid, tannin dan saponin merupakan senyawa yang bersifat antimikroba karena mampu menghambat aktivitas pertumbuhan bakteri. Flavonoid merupakan golongan fenol yang terdapat di tumbuhan berpembuluh, salah satu jenis flavonoid adalah galokatekin yang terdapat pada tanaman teh. (Mangunwardoyo dkk, 2009). Berdasarkan penelitian Razak, et al (2011) yang melakukan skrining terhadap kulit jengkol untuk di aplikasikan sebagai zat yang mampu menurunkan kadar gula darah menunjukan adanya kandungan terpenoid dan fenolic. Data hasil skrining menunjukkan hampir seluruh sampel memiliki kandungan fenolat dan terpenoid sehingga berpotensi untuk dikembangkan sebagai bahan alam yang mampu menurunkan kadar gula darah, namun hal ini harus dikaji lebih rinci lagi agar diperoleh isolate yang tepat untuk mensintesis zat hipoglikemi tersebut. Menurut beberapa ahli pernah mengungkapkan bahwa alkaloid diperkirakan sebagai pelindung tumbuhan dari serangan hama dan penyakit, pengatur tumbuh, atau sebagai basa mineral untuk mempertahankan keseimbangan ion (Putra, 2007). Sehingga kajian manfaat limbah jengkol yang berupa cangkang dan kulit batang ini dapat semakin luas ke depannya.

\section{Kesimpulan}

Cangkang dan kulit batang tanaman jengkol memiliki kandungan fitokimia yang bervariasi. Kandungan yang dimiliki oleh seluruh sampel cangkang dan kulit batang jengkol adalah flavonoid, saponin, dan monoterpen, sedangkan pada kandungan alkaloid, polifenol, dan kuinon sebagian besar menunjukkan hasil positif namun masih terdapat beberapa sampel yang menunjukkan hasil negatif.

\section{Ucapan Terima Kasih}

Penelitian ini di danai oleh skema Hibah Kompetitif Unpad tahun 2013.

\section{Daftar Pustaka}

Astika, W dan B. Sriyadi. 1995. BOTANI dalam Petunjuk Kultur Teknis Tanaman Kina. PPTK Gambung.

Elysa. 2011. Uji efek ekstrak etanol biji jengkol (Pithecellobium lobatum Benth.) terhadap penurunan kadar glukosa darah tikus putih 
jantan galur wistar yang diinduksi aloksan. USU diakses pada 32 September 2013 http://repository.usu.ac.id/bitstream/123 456789/29524/4/Chapter\%20II.pdf.

Evacuasiany E, H. William, dan S. Santosa. 2004. Pengaruh biji jengkol (Pithecellobium jiringa) terhadap kadar glukosa darah mencit galur Balb/c. JKMVol. 4, No. 1

Harborne, J.B. 1996. Metode Fitokimia Penuntun Cara Modern Menganalisis Tumbuhan. Bandung: Penerbit ITB. P.76- 153.

Kompas. 2013. Lampaui harga daging ayam jengkol hilang di pasar Tasikmalaya. Diakses 2 september 2013 di http://tekno.kompas.com/read/2013/06/ 04/17031434/lampaui.harga.daging.ayam.j engkol.hilang.di.pasar.tasikmalaya

Malik .S. A. M,. 2010. A Pithecellobium jiringa: A traditional medicinal herb. Webmed Cental. Article ID: WMC001371 diakses pada 2 september 2013 di http://www. webmedcentral.com/wmcpdf/Article_WM C001371.pdf
Mangunwardoyo, W., E. Cahyaningsih, dan T. Usia. 2009. Ekstraksi dan identifikasi senyawa antimikroba herba meniran (Phyllanthus niruri L.). J. Ilmu Kefarmasian Indonesia. Vol. 7, No. 2 http://jifi.ffup.org/ wp-content/uploads/2009/12/3.fulltexPDF5.pdf

Maxiselly, Y. dan D. Ustari. 2014. Explorasi tanaman jengkol di home garden kabupaten Ciamis Jawa Barat. Kultivasi Vol 13 No. 12014 hal 1-5.

Putra S.E. 2007. Alkaloid senyawa organic terbanyak di alam. Diakses 1 Desember 2013 di http://www.chem-is-try.org/ artikel_kimia/biokimia/alkaloid_senyawa _organik_terbanyak_di_alam/

Razak A, K., M. H Norazian., A. Syamsul, M. Isa, and M.T Nurhaya. 2010. The inhibition of glucose absorption of seed and pericarp extracts of Pithecellobium jiringa on intestinal tissues preparation and their phytochemical profiles. Poster. IIUM fundamental research grant (IFRG0701-31) 